University of Nebraska - Lincoln

DigitalCommons@University of Nebraska - Lincoln

Publications from USDA-ARS / UNL Faculty

U.S. Department of Agriculture: Agricultural

Research Service, Lincoln, Nebraska

1995

\title{
Volatilization of Alachlor and Atrazine as Influenced by Surface Litter
}

Timothy Gish

USDA-ARS

Ali Sadeghi

USDA-ARS

Brian J. Wienhold

University of Nebraska-Lincoln, Brian.Wienhold@ars.usda.gov

Follow this and additional works at: https://digitalcommons.unl.edu/usdaarsfacpub

Gish, Timothy; Sadeghi, Ali; and Wienhold, Brian J., "Volatilization of Alachlor and Atrazine as Influenced by Surface Litter" (1995). Publications from USDA-ARS / UNL Faculty. 1191.

https://digitalcommons.unl.edu/usdaarsfacpub/1191

This Article is brought to you for free and open access by the U.S. Department of Agriculture: Agricultural Research Service, Lincoln, Nebraska at DigitalCommons@University of Nebraska - Lincoln. It has been accepted for inclusion in Publications from USDA-ARS / UNL Faculty by an authorized administrator of DigitalCommons@University of Nebraska - Lincoln. 


\title{
Volatilization of Alachlor and Atravine as Influenced by Surface Litter
}

\author{
Timothy J. Gish*, Ali Sadeghi“*, and Brian J. Wienhold“**
}

- Soil Physicist, Hydrology Laboratory, Natural Resources Institute, U. S. Department of Agriculture, Agricultural Research Service, Beltsville, Maryland 20705, USA.

-* Soil Scientist, Environmental Chemistry Laboratory, Natural Resources Institute, U. S. Department of Agriculture, Agricultural Research Service, Beltsville, Maryland 20705, USA.

*.* Soil Scientist, Northern Great Plains Research Laboratory, U. S. Department of Agriculture, Agricultural Research Service, Mandan, North Dakota 58554, USA (Received in Germany 4 April 1995; accepted 1 June 1995)

\section{ABSTRACT}

A basic knowledge of how herbicide volatilization is influenced by agronomic practices is necessary if long-term detrimental impacts from herbicides are to be minimized. We measured cumulative herbicide volatilization losses in glass agroecosystem chambers to assess how surface residue conditions, simulated rainfall, temperature, and herbicide formulation affect volatilization of atrazine and alachlor. Research results demonstrated that herbicide volatilization before water application was greater under mulched conditions, but decreased dramatically after the first irrigation. As a result, after $35 \mathrm{~d}$ cumulative volatilization of atrazine from a mulched soil surface was less than half that from bare soil for both formulations. Plant litter on the soil surface and encapsulated herbicides may be viable alternatives for reducing volatilization of some herbicides in humid regions.

\section{INTRODUCTION}

Once volatilized, herbicide deposition may occur through rainfall events, fallout of particular matter to which the herbicide has become adsorbed, or by direct exchange between the atmosphere and the soil surface. To conserve natural resources, herbicide volatilization as affected by agricultural practices needs to be evaluated so as to prevent the development of management strategies which simply shift the herbicide from one part of the hydrologic cycle to another. Although no-tillage practices typically conserve water and soil, higher inputs of pesticides are frequently necessary to maintain yields (Christensen and Norris, 1983). Additionally, tillage practices affect pesticide behavior by altering soil temperature, soil water content, biological activity, and evaporation (Belvins et al., 1983; Tyler et al., 1983; Thomas and Frye, 1984; and Stearman et al., 1989). 
Conservation tillage practices typically favor the build up of an organic mulch on the soil surface. Consequently, a large portion of the surface-applied pesticide may be intercepted by plant residues (Ghadiri et al., 1984). The organic mulch could have a larger surface area and greater surface roughness perhaps resulting in higher volatilization losses (Glotfelty and Schomburg, 1989). On the other hand, Wienhold and Gish (1994a) observed a 50\% reduction in cumulative volatilization losses of alachlor and atrazine under no-tillage relative to tilled fields. A possible explanation for the reduction in herbicide volatility under no-tillage may be due to herbicide washoff from rainfall events that took place $3 \mathrm{~d}$ after application. In support of this hypothesis, Martin et al., (1978) observed that the first $0.5 \mathrm{~cm}$ of water was effective in washing atrazine from plant litter.

Formulation can also alter herbicide volatilization behavior. Microencapsulation of chlororpropham [isopropyl $\mathrm{m}$-chlorocarbanilate] in nylon capsules reduced volatilization losses five fold when compared to chloroproham applied as an emulsifiable concentrate (Turner $e t$ al., 1978). However, synthetic polymers may not be economical or biologically degradable, and thus not applicable to annual field use. Schreiber et al., (1987) suggested that herbicide encapsulation in a starch matrix would reduce volatilization and eliminate the long-term buildup of synthetic polymers in the field. Wienhold and Gish (1994a) found a reduction in herbicide volatilization with starchencapsulation, but the large granules used in their experiment gave questionable weed control in some areas of the mid-west U.S.. Recently, a smaller starch encapsulated granule was developed which gave favorable weed control (Schreiber $e t$ al., 1994). Herbicide rates of release, for a given herbicide, increase with decreasing granule size (Wienhold and Gish, 1994b). More rapid release reduces the time over which environmental fate may be modified.

The purpose of this study was to measure the volatilization of atrazine and alachlor applied as either a commercial formulation or as the smaller starch encapsulated granules when influenced by temperature, plant residue and precipitation.

\section{MATERIALS AND METHODS}

The experiment was conducted using five glass agroecoysytem chambers (1.5 m long, 0.5 $\mathrm{m}$ wide and $1.0 \mathrm{~m}$ tall) as model systems (Nash $e$ al., 1977)) The Monmouth sandy loam (Typic Hapludult) used in this experiment has a $\mathrm{pH}$ of 6.4 , organic matter content of $1.1 \%$, and a clay content of $5.6 \%$. Soil was placed in the bottom of each chamber to a depth of $17 \mathrm{~cm}$ and maintained at the assigned temperature by passing water from a constant temperature bath through a jacket surrounding the soil and through copper tubes buried within the soil. Temperatures used were 25 and $35^{\circ} \mathrm{C}$. The chambers were irrigated with a total of $10 \mathrm{~cm}$ of water, spray applied in $10,1-\mathrm{cm}$ increments during the $30 \mathrm{~d}$ study, in an attempt to simulate early spring rainfall common to the humid eastern U.S. The soil water potential in the top 5-cm was monitored daily in each chamber with soil tensiometers. Average surface water potentials were determined by averaging 
daily tensiometer readings for the four different chambers subjected to the same environmental constraints (same temperature and plant residue condition).

Atrazine [6-chloro- $\underline{N}$-ethyl- $\underline{\underline{N}}$ '-(1-methylethyl)-1,3,5-triazine-2,4-diamine] and alachlor [2chloro-N-(2,6-diethylphenyl)- $\mathrm{N}$-(methoxymethyl)-acetamide] was applied as either a commercial formulation (Bullet, Monsato Co., St Louis, $\mathrm{MO}^{1}$ ) or in a starch encapsulated formulation. Starch granules 0.425 to $0.85 \mathrm{~mm}$ in diameter used. Starch encapsulated atrazine contained $11.3 \%$ a.i. and alachlor $10.4 \%$ a.i. Both formulations were applied at the same rate: $1.7 \mathrm{~kg} \mathrm{ha}^{-1}$ for atrazine and $2.8 \mathrm{~kg} \mathrm{ha}^{-1}$ for alachlor. Starch encapsulated formulations were broadcast onto the soil surface while the commercial formulation was diluted in $100 \mathrm{~mL}$ of water and surface applied with a pump sprayer. An additional $100 \mathrm{~mL}$ of water, used to rinse out the sprayer, was also applied to the soil surface.

Volatilization of atrazine and alachlor for each treatment was measured in duplicate chambers. Since only five agroecosystem chambers were available, the experiment was divided into four 5 wk runs. The experimental treatments involved 2 temperatures $\left(25\right.$ and $\left.35^{\circ} \mathrm{C}\right), 2$ formulations (commercial and starch encapsulated), 2 surface conditions (mulched and bare), and 2 replicates. One chamber was used as a control during each run to determine if air drawn into the chambers contained any atrazine or alachlor and to insure that the soil used did not contain any residual herbicide.

Plant litter amount for the mulched soil surface treatments was determined from field observations on an established no-tillage field being used as a herbicide control. Ten field samples, each $0.75 \mathrm{~m}^{2}$, were randomly chosen and measured for plant litter. The average plant litter mass observed and subsequently used in the chambers was $521 \mathrm{gm}$. Plant residue consisted mainly of corn stubble and dried rye.

Air was continuously drawn through each chamber at a speed of $0.35 \mathrm{~km} \mathrm{~h}^{-1}\left(2.9 \mathrm{~m}^{3} \mathrm{~min}^{-1}\right)$ using high pressure direct drive suction fan attached to a manifold at the exit of each chamber. Air entered the chamber through 12 evenly spaced holes $(0.05-\mathrm{m}$ diam) present in the front $(0.5$ by $1.0 \mathrm{~m}$ ) wall of the chamber and exited through 12 evenly spaced holes in the back wall of the chamber. Each air entry hole was covered with glass fiber cloth to prevent the entrance of insects and dust. Each air exit hole contained a polyurethane foam plug $(5-\mathrm{cm})$ that trapped any herbicide present in the vapor phase (Turner and Glotfelty, 1977).

Polyurethane plugs were replaced $2,6 \mathrm{~h}, 1,2$, and $3 \mathrm{~d}$, and 1, 2,3, 4, and $5 \mathrm{wk}$ after application. Plugs were soxhlet extracted with $150 \mathrm{~mL}$ ethyl acetate for $3 \mathrm{~h}$. The extract was rotevaporated to dryness and redissolved in $10 \mathrm{~mL}$ of ethyl acetate containing trifluralin [2,6dinitro- $\underline{N}, \underline{N}$-dipropyl-4-(trifluoromethyl) benzenamine) as an internal standard. Atrazine and

\footnotetext{
${ }^{1}$ Trade names or company names are included for the benefit of the reader and imply no endorsement or preferential treatment of the product listed by USDA.
} 
alachlor concentrations were determined using a gas chromatograph equipped with a

nitrogen-phosphorus detector. Operating conditions for the gas chromatograph were: $30 \mathrm{~m} \times 0.32$ $\mathrm{mm}$ id glass capillary column coated with $0.26 \mu \mathrm{m}$ SPB-5 (Supelco Inc., Bellefonte, PA); injector temperature, $200^{\circ} \mathrm{C}$; oven temperature $150^{\circ} \mathrm{C}$; detector temperature, $220^{\circ} \mathrm{C}$; and a He carrier gas flow rate of $2.5 \mathrm{~mL} \mathrm{~min}^{-1}$.

\section{RESULTS AND DISCUSSION}

Temperature and soil water availability have a strong influence on herbicide rate of release from the starch granules. Herbicide rates of release increase with water availability and temperature (Wienhold and Gish, 1992). Average surface water potentials in the

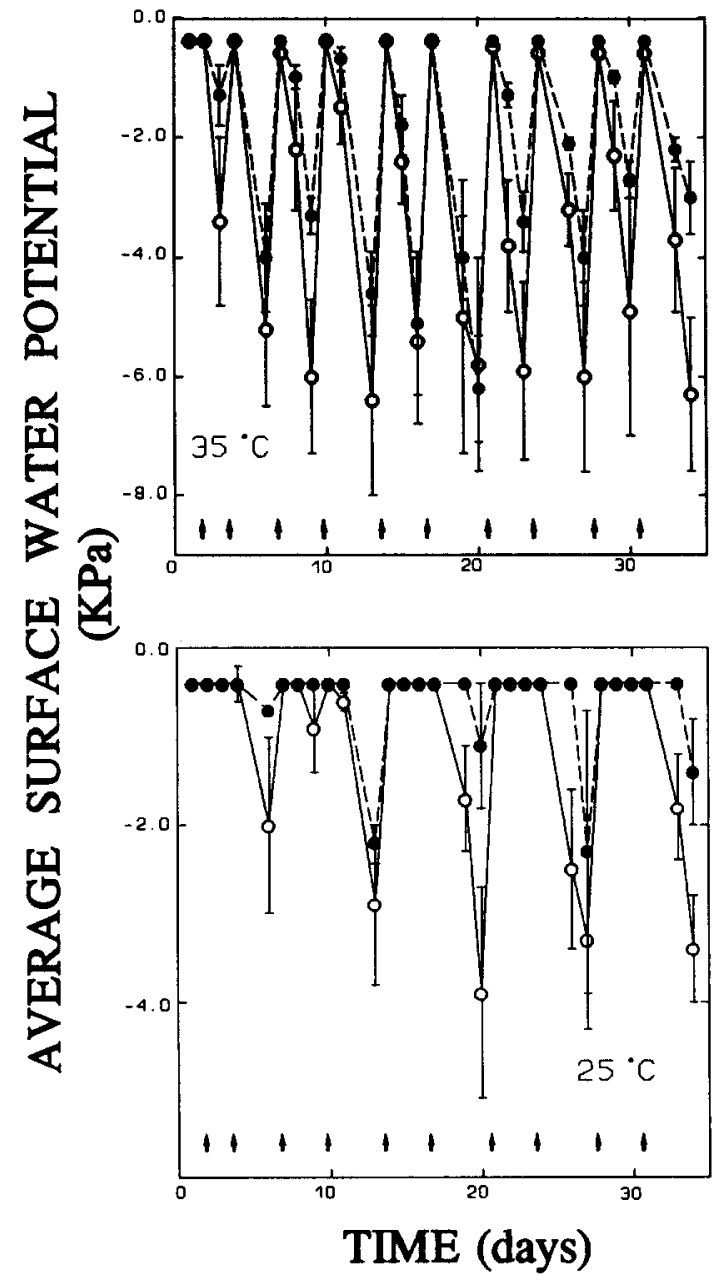

Fig. 1. Average surface soil water potential for bare $(0)$ and mulched $(\bullet)$ soil surfaces as influenced by soil temperature and irrigation. Error bars indicate \pm standard error of the mean. 
ocosystem chambers were less at 35 than at $25^{\circ} \mathrm{C}$ (Fig. 1). At $35^{\circ} \mathrm{C}$, the surface soil dried out to at least $-5.0 \mathrm{KPa}$ twice a week, whereas at $25^{\circ} \mathrm{C}$, the surface soil was moist and rarely dried out to $-3.0 \mathrm{KPa}$. For both temperatures the mulched surface soil had a higher soil water potential.

Additionally, standard error of the mean values for the surface water potential were less under mulched surface conditions than in bare soil.

Surface water potentials for the $25^{\circ} \mathrm{C}$ chambers suggest that for this water input frequency, starch granules will readily imbibe water, swell, and herbicide release will be rapid (Wienhold and Gish, 1992). At $35^{\circ} \mathrm{C}$, herbicide rates of release and subsequent volatilization is more dynamic. For example, increases in temperature on a continuously moist soil lead to increased rates of



Fig. 2. Cumulative atrazine volatilization from soil as influenced by temperature, soil surface condition, and formulation. Error bars denote the range of values observed. Note differences in y-axis scale among graphs. 
release and enhanced volatilization (Wienhold et al., 1993). However, as the soil becomes drier, rates of release decline (Wienhold and Gish, 1992). At $35^{\circ} \mathrm{C}$, evaporation rates were sufficiently high to dry the soil surface. The cyclic pattern to the surface water potential, at $35^{\circ} \mathrm{C}$, indicates periods of alternating fast and slow herbicide release from the starch granules, a condition common to most field conditions.

Cumulative volatilization of atrazine increased with temperature for all surface and formulation treatments (Fig. 2). Volatilization of the commercially formulated atrazine at $35^{\circ} \mathrm{C}$ was twice that at $25^{\circ} \mathrm{C}$ for both surface conditions. For each formulation, atrazine volatilization was greatest under mulched conditions before irrigation, but dropped below the atrazine volatilization losses from a bare soil after the first irrigation $(1 \mathrm{~cm}$ water). After $35 \mathrm{~d}$, cumulative volatilization of commercially formulated atrazine under bare soil conditions ranged from about $4 \%$ of that applied at $25^{\circ} \mathrm{C}$, to about $9 \%$ at $35^{\circ} \mathrm{C}$. After $35 \mathrm{~d}$, cumulative volatilization of commercially formulated atrazine from a mulched soil ranged from about $2 \%$ at $25^{\circ} \mathrm{C}$, to about $6 \%$ at $35^{\circ} \mathrm{C}$. Glotfelty et al., (1989) measured atrazine volatilization losses from a fallow field and found $2.4 \%$ of the applied chemical was lost after $24 \mathrm{~d}$. Wienhold and Gish (1994a) measured commercial formulated atrazine volatilization losses of $9 \%$ of that applied to a tilled soil and $4 \%$ under no-tillage. If one considers nightly cooling and drying, differences in soil properties, and precipitation these results appear reasonable for commercial formulated atrazine (Taylor and Spencer, 1990).

Atrazine is a relatively persistent herbicide (Table 1 ). Consequently, atrazine volatilization may also occur over long durations. Cumulative atrazine volatilization losses in this experiment do not appear to have reached asymptotic values after $35 \mathrm{~d}$. Although atrazine volatilization rates are decreasing, the cumulative atrazine losses at 25 and $35^{\circ} \mathrm{C}$ indicate a potential source for

Table 1. Chemical properties for atrazine and alachlor at $25^{\circ} \mathrm{C}$

Chemical

property Atrazine Alachlor

Solubility in water $\left(\mathrm{mg} \mathrm{L}^{-1}\right)$

Henry's Law
constant, $\mathbf{K}_{\mathrm{H}}$
$2.5 \times 10^{-7}$
$1.3 \times 10^{-6}$

Dissipation

half-lives 
environmental contamination. In support of these findings, Glotfelty et al., (1990) observed atrazine deposition in rain near the Wye River in Maryland over a 4 to 5 month period.

Volatilization of starch encapsulated atrazine was less than the commercial formulation for both the bare and mulched soil surfaces (Figs. 2). Cumulative volatilization of starch encapsulated atrazine was nearly 3 times greater at $35^{\circ} \mathrm{C}$ than at $25^{\circ} \mathrm{C}$ for both bare and mulched soil surfaces. After $35 \mathrm{~d}$, cumulative volatilization of starch encapsulated atrazine under bare soil conditions ranged from about $1 \%$ at $25^{\circ} \mathrm{C}$, to about $5 \%$ at $35^{\circ} \mathrm{C}$. On a mulched soil surface the $35 \mathrm{~d}$, cumulative volatilization losses of atrazine was reduced to $<1 \%$ of that applied at $25^{\circ} \mathrm{C}$, to about $2 \%$ at $35^{\circ} \mathrm{C}$. Atrazine volatilization losses from the smaller starch granules used in this study were nearly twice that reported by Wienhold and Gish (1994a). The lower volatilization losses reported earlier are the result of larger starch granules, and the subsequent slower rate of release (Wienhold and Gish, 1994b). At a water potential of O MPa, it takes about $30 \mathrm{~d}$ to achieve a $97 \%$ release of atrazine from the larger starch granules while for the smaller granules it takes only $16 \mathrm{~d}$ (Wienhold and Gish, 1994b). Nonetheless, volatilization of starch encapsulated atrazine was consistently lower than the commercial formulation regardless of soil moisture status and surface condition.

Cumulative volatilization losses for commercial alachlor were substantial (Fig. 3.). After 35 days, cumulative alachlor losses on a bare soil ranged from about $6 \%$ at $25^{\circ} \mathrm{C}$, to about $13 \%$ at $35^{\circ} \mathrm{C}$. There was no significant difference in volatilization of commercially formulated alachlor between bare and mulched soil surfaces at either 25 or $35^{\circ} \mathrm{C}$. Volatilization losses of commercial alachlor were slightly less in this experiment than under the field conditions observed by Wienhold and Gish (1994a) who measured alachlor volatilization losses of about $8 \%$ under no-tillage (mulched surface) and about $13 \%$ for a tilled field. Although the same application rates of alachlor were used in both the field and this ecosystem study the water input patterns were different. In the field experiment, most of the precipitation came $6 \mathrm{~d}$ of application during three rain events (Wienhold and Gish, 1994a). In the greenhouse, 1-cm irrigations were spaced uniformly throughout the $5 \mathrm{wk}$ period. The frequent smaller water inputs may be more effective in leaching alachlor into the soil subsurface where it would be less susceptible to volatilization (Philip, 1984).

Cumulative volatilization of starch encapsulated alachlor from the mulched soil surface was lower than all of the formulation and surface treatments. After $35 \mathrm{~d}$, about $2 \%$ of the applied alachlor had volatilized at $25^{\circ} \mathrm{C}$ whereas about $8 \%$ had volatilized at $35^{\circ} \mathrm{C}$. These alachlor losses are slightly less than those observed in the field where larger granules were used (Wienhold and Gish, 1994a). Again, it may be that the high solubility of alachlor and the frequent small irrigations favor alachlor transport into the subsoil where it is less susceptible to volatilization.

The greatest herbicide volatilization losses occurred with starch encapsulated alachlor from a bare soil surface. After $35 \mathrm{~d}$, about $8 \%$ of the applied starch encapsulated alachlor had 


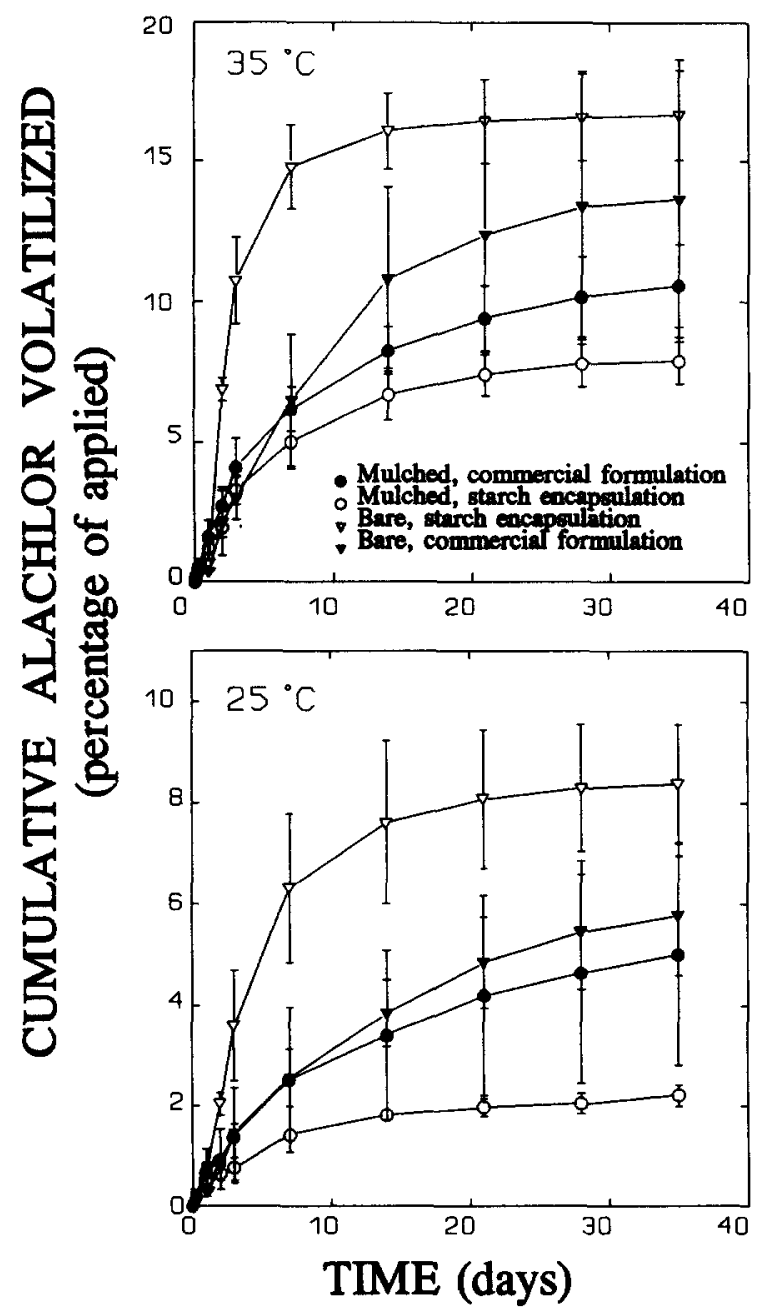

Fig. 3. Cumulative alachlor from soil as influenced by temperature, soil surface condition, and formulation. Error bars denote range in values observed. Note differences in y-axis scale among graphs.

volatilized at $25^{\circ} \mathrm{C}$ while about $17 \%$ had volatilized at $35^{\circ} \mathrm{C}$. High volatilization losses of starch encapsulated alachlor from bare, moist soils have been observed before (Wienhold et al., 1993; Wienhold and Gish, 1994a). The higher volatilization losses of alachlor relative to atrazine from bare soils have been attributed to granule effects (localized high concentrations, low affinity of the granule for alachlor) and pesticide characteristics (solubility and $\mathrm{K}_{\mathrm{H}}$ ) (Table 1).

Alachlor volatilization losses appear to reach asymptotic values by $35 \mathrm{~d}$. Although alachlor is more volatile it is also less persistent (Table 1). As a result, alachlor volatilization rates will be 
greater during the first two weeks after application, but will also reach asymptotic levels before atrazine. Glotfelty et al., (1990) found that while atrazine in rain water lasted over many months, alachlor was present in the atmosphere for only short periods of time. Alachlor levels in rain water dropped to undetectable levels within 1 to 2 wks after application.

Volatilization of atrazine and alachlor were strongly influenced by the presence of surface litter and herbicide formulation. In this experiment, a $1-\mathrm{cm}$ irrigation appears to wash herbicides off plant residue. Once below the surface litter, the herbicides had to diffuse through a stagnant air region below the surface litter. Reduced air movement at the soil-atmosphere interface reduced volatilization though soil moisture conditions favored volatilization under mulched conditions when compared to bare soil (Fig. 2 and 3). However, it also appears that the mulched surface has less of an impact on volatilization of commercially formulated alachlor than atrazine. The relatively larger $\mathrm{K}_{\mathrm{H}}$ value for alachlor reduces the impact of the stagnant boundary layer which formed under mulched conditions. Spencer et al., (1988) also found that volatilization of organics with low $\mathrm{K}_{\mathrm{H}}$ values are controlled by the air-boundary layer above the soil surface, while those with higher $\mathrm{K}_{H}$ values are less influenced by a stagnant air layer. In addition, starch encapsulation also appears to reduce herbicide volatilization when used in combination with a mulched soil surface. The decrease in starch encapsulated alachlor volatilization with the mulched conditions may be related to the micro-environment of the pesticide after application. From field tests, $>60 \%$ of the recovered spray-applied alachlor was associated with the surface plant litter, while $<5 \%$ of the starch-encapsulated alachlor was associated with the surface litter.

In comparison to larger starch granules, the smaller granule size appears to increase atrazine volatilization, but had little impact on alachlor volatilization. It may be that the reduction in granule size was negligible when compared to the fast release rates associated with alachlor's solubility. To ascertain whether or not the smaller granule size is shifting the herbicide to other parts of the hydrologic cycle, both field runoff and leaching studies should be conducted.

\section{REFERENCES}

Christensen, L. A. and P. E. Norris (1983) A comparison of tillage systems for reducing soil erosion and water pollution. Agric. Econ. Rep. No. 499, U. S. Dept. Agric., Washington, DC. pp.27.

Blevins, R. L., G. W. Thomas, Ms. Smith, W.W. Frye, and P. L. Cornelius (1983) Changes in soil properties after 10 years continuous non-tilled and conventionally tilled corn. Soil Tillage Res. 3:135-145. 
Ghadiri, H., P. J. Shea, and G. A. Wicks (1984) Interception and retention of atrazine by wheat (Triticum aestivum L.) stubble. Weed Sci. 32:24-27.

Gish, T. J., A. Shirmohammadi, and B. J. Wienhold (1994) Field-scale mobility and persistence of commercial and starch-encapsulated atrazine and alachlor. J. Environ. Qual. 23:355-359.

Glotfelty, D. E., M. M. Leech, J. Jersey, and A. W. Taylor (1989) Volatilization and wind erosion of soil surface applied atrazine, simazine, alachlor, and toxaphene. J. Agric. Food Chem. 37:546-551.

Glotfelty, D. E. and C. J. Schomburg (1989) Volatilization of pesticides from soil. p.181-207. In B. L. Sawhney and K. Brown (ed.) Reaction and movement of organic chemicals in soils. Soil Sci. Soc. Am., Madison, WI.

Glotfelty, D. E., G. H. Williams, H. P. Freeman, and M. M. Leech (1990) Regional atmospheric transport and deposition of pesticides in Maryland. pp 199221. In D. A. Kurtz (ed) Long range transport of pesticides. Lewis Publ. Inc., Chelsea, MI.

Martin, C. D., J. L. Baker, D. C. Erbach, and H. P. Johnson (1978) Washoff of herbicides applied to corn residue. Transactions ASAE 21:1164-1168.

Nash, R. G., M. L. Beall, Jr., and W. G. Harris (1977) Toxaphene and 1,1,1trichloro-2, 2-bis(p-chlorophenyl)ethane (DDT) losses from cotton in an agroecosystem chamber. J. Agric. Food Chem. 25:336-341.

Philip, J. R (1984) Nonuniform leaching from nonuniform steady infiltration. Soil Sci. Soc. Am. J. 48:740-749.

Schreiber, M. M., B. S. Shasha, D. Trimnell, and M. D. White (1987) Controlled release herbicides. Monogr. Ser. Weed Sci. Soc. Am. 4:177-191.

Schreiber, M. M., M. V. Hickman, and G. D. Vail (1994) Efficacy of starchencapsulated formulations of atrazine containing two or three herbicides in same granule. Weed Tech. 8:105-113. 
Spencer, W. F., M. M. Claith, W. A. Jury, and Lian-Zhong Zhang (1988)

Volatilization of organic chemicals from soil as related to their Henry's law constant. J. Environ. Qual. 17:504-509.

Stearman, G. K., R. J. Lewis, L. J. Tortorelli, and D. D. Taylor (1989) Herbicide reactivity of soil organic matter in no-tilled and tilled cotton. Soil Sci. Soc. Am. J. 53:1690-1694.

Taylor, A. W. and W. F. Spencer (1990) Volatilization and vapor transport processes. p. 213-269. In H.H. Cheng (ed.) Pesticides in soil environment: processes, impacts, and modeling. Soil Sci. Soc. Am., Madison, WI.

Thomas, G. W. and W. W. Frye (1984) Fertilization and liming. p.87-126. In R. E. Phillips and S. H. Phillips (ed.) No-tillage agriculture. Van Nostrand Reinhold Co., New York.

Turner, B. C. and D. E. Glotfelty (1977) Field air sampling of pesticide vapors with polyurethane foam. Anal. Chem. 49:7-10.

Turner, B. C., D. E. Glotfelty, A. W. Taylor, and D. R. Watson (1978) Volatilization of microencapsulated and conventionally applied chlorpropam in the field. Agron. J. 70:933-937.

Tyler, D. D., J. R. Overton, and A. Y. Chambers (1983) Tillage effects on soil properties, disease, cyst nematodes, and soybean yields. J. Soil Water Conserv. 38:374-376.

Wienhold, B. J., A. Sadeghi, and T. J. Gish (1993) Effect of temperature and formulation on volatilization of atrazine and alachlor. J. Environ. Qual. 22:162-166.

Wienhold, B. J. and T. J. Gish (1992). Effect of water potential, temperature, and microbial activity on release of starch encapsulated atrazine and alachlor. J. Environ. Qual. 21:382-386.

Wienhold, B. J. and T. J. Gish (1994a) Effect of formulation and tillage practice on volatilization of atrazine and alachlor. J. Environ. Qual. 23:292-298. 
Wienhold, B. J. and T. J. Gish (1994b) Chemical properties influencing rate of release of starch encapsulated herbicides. Implications for modifying environmental fate.

Chemosphere. 28:1035-1046. 